\title{
SUPT6H Gene
}

National Cancer Institute

\section{Source}

National Cancer Institute. SUPT6H Gene. NCI Thesaurus. Code C18390.

This gene plays a role in the positive regulation of transcriptional elong ation. It is also involved in the modification of chromatin. 